\title{
Quality Assessment of Five Different Brands of Chyawanprash Marketed in Nepal
}

\author{
Babita Aryal $\mathbb{D}^{1},{ }^{1}$ Prem Paudyal $\left(\mathbb{D},{ }^{2}\right.$ Krishma Ghimire $\mathbb{D}^{2},{ }^{2}$ Sabitra Sharma ${ }^{D},{ }^{3}$ \\ and Dharma Prasad Khanal $\mathbb{(}^{2}$ \\ ${ }^{1}$ Biological Chemistry Lab, Central Department of Chemistry, Tribhuvan University, Kirtipur, Nepal \\ ${ }^{2}$ Department of Pharmacy, Manmohan Memorial Institute of Health Sciences, Kathmandu, Nepal \\ ${ }^{3}$ Central Department of Botany, Tribhuvan University, Kathmandu, Nepal \\ Correspondence should be addressed to Babita Aryal; babitaaryal13@gmail.com
}

Received 28 July 2021; Revised 20 October 2021; Accepted 13 November 2021; Published 29 November 2021

Academic Editor: Antimo Di Maro

Copyright ( $) 2021$ Babita Aryal et al. This is an open access article distributed under the Creative Commons Attribution License, which permits unrestricted use, distribution, and reproduction in any medium, provided the original work is properly cited.

Chyawanprash, a polyherbal formulation, is popular for its nutritional value and is widely used as a tonic, rejuvenator, immunomodulator, and enhancer. This study aimed to evaluate the quality profile of five different brands of Chyawanprash marketed in Nepal. Proximate analysis, estimation of heavy metal, physicochemical analysis, determination of microbial contamination, estimation of vitamin C, and detection of heavy metals were carried out to assess the therapeutical values and compare the quality control parameters. All the analyses were carried out based on standard procedures. The data analysis revealed that the presence of moisture content $(11.83 \pm 1.61 \%-19.90 \pm 0.92 \%)$, ash content (1.2-2.3\%), energy (316.12 $\pm 1.96-363 \pm 11.90 \mathrm{Kcal} / 100 \mathrm{~g})$, acid-insoluble ash content $(0.12 \pm 0.05-1.47 \pm 0.26 \%)$, $\mathrm{pH}(5.12-5.34)$, vitamin $\mathrm{C}(9.92-28.58 \mathrm{mg} / 100 \mathrm{~g})$, and heavy metals was not detected in ppm in any of the brands. Chyawanprash holds tremendous amounts of nutritional value suitable for treating different types of illness. Thus, stringent quality control parameters should be implemented from the government level for product consistency and to reduce variation among different brands.

\section{Introduction}

Chyawanprash is a brown-colored semisolid jam with a sweet and tangy taste, prepared through the synergistic unification of more than 50 herbs, spices, and processed minerals in specific quantities. It is placed under Rasayana in Ayurveda, which promotes the body's integrity or health via improving digestion, delaying aging process, eradicating degenerative processes, and many more [1]. The key plant ingredients of Chyawanprash are Amala (Phyllanthus emblica), Guduchi (Tinospora cordifolia), Shatavari (Asparagus racemosus), Brahmi (Bacopa monnieri), Ashwagandha (Withania somnifera), Bala (Sida cordifolia), Pippali (Piper longum), Gokshura (Tribulus terrestris), and so forth. Chyawanprash preparation is described in the ancient books, namely, Ashtanga Hridayam, Charaka Samhita, and Sangandhara Samhita. Other than herbs, sugar, honey, ghee, sesame oil, and preservative are present on Chyawanprash [2].
Chyawanprash is a nutritional and functional food rich in different phytoconstituents such as polyphenols, alkaloids, saponins, terpenes, and diverse health or medicinal benefits [1]. Chyawanprash, popular for nutritive worth, is a natural tonic utilized by people all around the world. It is used to protect and strengthen the respiratory system by treating cough, asthmatic breathing, bronchial spasm, and common cold. It is also used as an adjunct to the antitubercular drug [3]. Additionally, it is useful as a tonic, rejuvenator, anabolic, memory enhancer, and an immunomodulatory agent. Phytoconstituents of Chyawanprash exhibited a wide range of pharmaceutical activities such as antioxidant, antimicrobial, anti-inflammatory, immune-modulatory activities, and several beneficial effects on the digestive, cardiovascular, respiratory, metabolic, reproductive, and nervous systems, respectively [4-7].

However, the safety and efficacy of herbal drugs depend upon the sources and the quality of raw materials such as 
storage and transportation, temperature, light exposure, drying, packing, age and parts of the plant collected, good manufacturing practices (GMP), contaminations such as microbial contamination, pesticide residues, intentional or unintentional adulteration with heavy metal, allopathic drugs such as steroids, and nonsteroidal anti-inflammatory drugs (NSAIDs), which can directly affect the quality and the therapeutic value of herbal medicines $[8,9]$. Hence, the quality control of the ayurvedic formulation using modern analysis techniques is very important [10].

Therefore, this study aimed to establish and validate the quality control parameters of the Nepali market. This study also aimed to compare the quality control parameters of different marketed Chyawanprash preparations.

\section{Materials and Methods}

2.1. Collection of Chyawanprash. Five different brands of Chyawanprash (A, B, C, D, and E) were collected from different ayurvedic pharmacies, and the date of manufacturing and expiry was recorded. The study was conducted in the Manmohan Memorial Institute of Health Sciences (MMIHS) Research Laboratory, Department of Food Technology and Quality Control, Ministry of Agriculture and Cooperatives, Babarmahal, Kathmandu, and Nepal Bureau of Standards and Metrology, Machhapokhari, Kathmandu.

2.2. Proximate Composition. Proximate composition of samples was determined according to the method of Association of Official Analytical Chemists (AOAC) 1990 [11].

2.2.1. Determination of Moisture Content. The determination of moisture content was performed following AOAC 934.01 method [11], using vacuum oven. Briefly, the percentage of moisture present in the samples was calculated using the following formula:

$$
\text { Moisture \% by weight }=\frac{100\left(W_{1}-W_{2}\right)}{\left(W_{1}-W\right)} \times 100 \text {. }
$$

Here, $W_{1}$ is the weight of the crucible in $g$ with samples before drying, $W_{2}$ is the weight of the crucible in $g$ with samples after drying, and $W$ is the weight of the empty crucible in $\mathrm{g}$ after heating and cooling.

2.2.2. Determination of Total Ash. The total ash content in the samples was determined using AOAC 923.03 method. The ash percentage was then calculated using equation (1). Here, $W_{2}$ is the weight of crucible containing ash in $\mathrm{g}, W$ is the weight of empty crucible in $g$, and $W_{1}$ is the weight of initial samples in $\mathrm{g}$.

2.2.3. Determination of Crude Fat. The crude fat in the sample was determined by the Soxhlet extraction using benzyl ether as solvent based on AOAC 948.22 method. The crude fat percent was calculated using equation (1). Here, $W_{1}$ is the weight of flat-bottomed flask with dried ether extract in $\mathrm{g}, W_{2}$ is the weight of the flat-bottomed flask in $\mathrm{g}$, and $W$ is the weight of the samples taken for extraction in $g$.

2.2.4. Determination of Crude Fiber. The determination of crude fiber in the samples was performed using AOAC 962.09 method. The percentage of the crude fiber was calculated using equation (1).

2.2.5. Determination of Crude Protein. The protein was determined using the Kjeldahl method of AOAC 2001.11. The percentage of nitrogen was calculated by the following equation:

$$
\text { Total nitrogen percent by weight }=\frac{1.4 \times N \times 10\left(V-V_{1}\right)}{W}
$$

$$
=X \text {, }
$$

where $V$ is the volume of standard acid used to neutralize the distillate, $V_{1}$ is the volume of standard acid used to neutralize the blank, $N$ is the normality of the standard acid, and $W$ is the weight of samples in g. $X$ is total nitrogen rate, $1.4=$ factor.

The rate of crude protein was determined by multiplying the percentage of nitrogen by 6.25 .

Protein percentage $=$ percentage of nitrogen $\times 6.25$.

2.2.6. Determination of Carbohydrate. The total carbohydrate content in the samples was determined by the AOAC method from the following constituents: percentage of moisture, total ash, total fat, total protein, and total fiber using the following equation:

$$
\text { Carbohydrate } \%=[100-\{M+A+F+P+\text { Fib }\}] .
$$

Here, $M$ is the percentage of total moisture, $A$ is the percentage of total ash, $F$ is the percentage of total fat, $P$ is the percentage of total protein, and Fib is the percentage of total fiber.

2.2.7. Determination of Total Energy. The total energy value was determined based on energizing values of proteins, total carbohydrates, and fat by Merril and Watt (1955) coefficients adopted by the Food and Agriculture Organization in 1970. The total energy value of the sample was determined by the following equation:

$$
\left[(P+C) x_{4}+\mathrm{Fx} 9\right]=\frac{\mathrm{Xkcal}}{100}
$$

where $P$ is the percentage of protein, $C$ is the percentage of carbohydrate, $F$ is the percentage of fat, and $X$ is total energy.

2.3. Physicochemical Analyses. The physicochemical analyses were performed according to the Ayurvedic Pharmacopoeia of India [12]. 
2.3.1. Determination of $p H$. The $\mathrm{pH}$ of each sample was determined by preparing a $1 \% \mathrm{w} / \mathrm{v}$ aqueous solution of the samples and was measured using a $\mathrm{pH}$ meter.

2.3.2. Determination of Acid-Insoluble Ash. The acidinsoluble ash contained was determined using dilute hydrochloric acid.

The content of acid-insoluble ash was calculated using the following formula:

$$
\text { Acid - Insoluble Ash \% }=\frac{100\left(W_{1}\right)}{W_{2}} \text {. }
$$

2.3.3. Determination of Alcohol-Soluble Extractive. The alcohol-soluble extractive analyses were performed according to the Ayurvedic Pharmacopoeia of India [12].
The alcohol-soluble extractive was calculated using equation (5).

2.3.4. Determination of Water-Soluble Extractive. The water-soluble extractive analyses were performed according to the Ayurvedic Pharmacopoeia of India. The water-soluble extractive was calculated using equation (5).

2.4. Estimation of Vitamin $C$. The vitamin $\mathrm{C}$ content was determined using 2, 6-dichlorophenol-indophenol visual titration method [13].

The ascorbic acid content of the samples was determined by the following equation:

mg of ascorbic acid per $100 \mathrm{~g}=\frac{\text { Titre } \times \text { Dye factor } \times \text { vol.made up }}{\text { Aliquot of extract } \times \text { weight of sample taken for estimation }} \times 100$.

2.5. Determination of Microbial Contamination and Identification of Microbes. For the pretreatment of the sample, $1 \mathrm{~g}$ of samples was homogenized in $10 \mathrm{ml}$ of sterilized buffered sodium chloride-peptone solution $\mathrm{pH} \mathrm{7,} \mathrm{which} \mathrm{was} \mathrm{then}$ used for further examination. Likewise, for the examination of the sample, $1 \mathrm{ml}$ of the prepared sample was then mixed with $15 \mathrm{ml}$ of liquefied casein soya bean digest agar at not more than $45^{\circ} \mathrm{C}$. The mixture was then poured into a Petri dish and allowed to incubate overnight at $37^{\circ} \mathrm{C}$. Obtained colonies were counted under the digital colony counter and reported. The obtained colonies were then subcultured in blood agar and MacConkey agar. The identification of significant isolates was done following the Gram staining procedure. Gram stain can be used effectively to divide all bacterial species into two large groups: those that take up the basic dye, crystal violet (Gram-positive), and those that allow the crystal dye to wash out quickly with the decolorizer alcohol or acetone (Gram-negative). The following steps are involved in Gram stain: a thin film of the bacterial culture to be examined was prepared and dried. The material on the slide was heat fixed and allowed to cool before staining. The slide was flooded with crystal violet stain and allowed to remain without drying for 30 to 60 seconds. The slide was rinsed with tap water, shaking off excess. The slide was flooded with iodine solution and allowed to remain on the surface without drying for twice as long as the crystal violet was in contact with the slide surface. Then, the slide was rinsed with tap water, shaking off excess. The slide was flooded with acetone alcohol decolorizer for 10 seconds and rinsed immediately with tap water until no further colors flowed from the slide with the decolorizer. The slide was flooded with counterstain (safranin) for 30 seconds and washed off with tap water, and the slide was blotted between two clean sheets of blotting paper and finally was examined microscopically under oil immersion at 100X.
2.6. Estimation of Heavy Metal, Lead, and Cadmium. The estimation of lead and cadmium in the samples was performed using a flame atomic absorption spectrophotometer [14]. The aqueous sample was aspirated in a flame atomizer by nebulizer to measure the analyte concentration at ppm concentration with good precision.

2.7. Statistical Analysis. For every test performed, there were three replicates for each sample. The calculations of average and standard deviations (SD) were done with the software EXCEL 2010. Data were reported as mean \pm standard deviation of triplicate measurements. The significant differences $(p<0.05)$ within means were analyzed by analysis of variance and significant difference test in the GraphPad Prism Software version 8 .

\section{Results}

3.1. Proximate Analyses. The proximate analyses such as moisture content, total ash, crude fat, crude fiber, crude protein, carbohydrate content, and total energy result are shown in Table 1 . The average moisture content was higher than the pharmacopoeial limit in all brands of Chyawanprash. Among them, brand $\mathrm{D}$ contained the highest level $(19.90 \pm 1.61 \mathrm{~g} / 100 \mathrm{~g})$ of moisture. According to API 2007, the total ash of Chyawanprash should not be more than $2 \%$. All the marketed formulations of Chyawanprash except brand $\mathrm{E}$ $(2.50 \pm 0.44 \mathrm{~g} / 100 \mathrm{~g})$ were below the limit. Brand $\mathrm{C}$ $(0.96 \pm 0.44 \mathrm{~g} / 100 \mathrm{~g})$ showed maximum crude fat of all the brands included in the study. It is then followed by brand $\mathrm{A}$ $(0.70 \pm 0.02 \mathrm{~g} / 100 \mathrm{~g})$, brand $\mathrm{D}(0.36 \pm 0.15 \mathrm{~g} / 100 \mathrm{~g})$, and brand E $(0.30 \pm 0.17 \mathrm{~g} / 100 \mathrm{~g})$. Brand B $(0.19 \pm 0.12 \mathrm{~g} / 100 \mathrm{~g})$ showed the least crude fat content. Brand $B$ was found to have the lowest crude fat, whereas brand $\mathrm{C}$ showed the maximum 
TABle 1: Proximate analyses of different brands of Chyawanprash (average \pm standard deviation).

\begin{tabular}{lccccc}
\hline Components $(\mathrm{g} / 100 \mathrm{~g})$ & Brand A & Brand B & Brand C & Brand D & Brand E \\
\hline Moisture & $11.83 \pm 0.92^{\mathrm{c}}$ & $18.74 \pm 0.6^{\mathrm{c}}$ & $19.90 \pm 0.83^{\mathrm{c}}$ & $11.83 \pm 1.6^{\mathrm{c}}$ & $16.40 \pm 1.67^{\mathrm{c}}$ \\
Total ash & $1.51 \pm 0.09$ & $0.57 \pm 0.40$ & $0.72 \pm 0.08$ & $0.87 \pm 0.36$ & $2.50 \pm 0.44$ \\
Fat & $0.70 \pm 0.02$ & $0.19 \pm 0.12$ & $0.96 \pm 0.44$ & $0.36 \pm 0.15$ & $0.30 \pm 0.17$ \\
Crude fiber & $1.09 \pm 0.04^{\mathrm{a}, \mathrm{d}}$ & $0.52 \pm 0.11^{\mathrm{a}, \mathrm{d}}$ & $0.09 \pm 0.002^{\mathrm{a}, \mathrm{d}}$ & $0.82 \pm 0.005^{\mathrm{a}, \mathrm{d}}$ & $0.40 \pm 0.016^{\mathrm{a}, \mathrm{d}}$ \\
Proteins & $4.42 \pm 0.38^{\mathrm{a}, \mathrm{c}}$ & $2.63 \pm 0.28^{\mathrm{a}, \mathrm{c}}$ & $0.60 \pm 0.25^{\mathrm{a}, \mathrm{c}}$ & $5.36 \pm 0.83^{\mathrm{a}, \mathrm{c}}$ & $2.02 \pm 0.29^{\mathrm{a}, \mathrm{c}}$ \\
Carbohydrate & $73.01 \pm 0.71^{\mathrm{b}}$ & $81.80 \pm 1.62^{\mathrm{b}}$ & $88.13 \pm 1.78^{\mathrm{b}}$ & $82.72 \pm 0.62^{\mathrm{b}}$ & $80.35 \pm 0.53^{\mathrm{b}}$ \\
Total energy (Kcal/100g) & $316.12 \pm 1.96^{\mathrm{b}, \mathrm{d}}$ & $339.54 \pm 4.77^{\mathrm{b}, \mathrm{d}}$ & $363 \pm 11.90^{\mathrm{b}, \mathrm{d}}$ & $355 \pm 5.07^{\mathrm{b}, \mathrm{d}}$ & $332 \pm 0.22^{\mathrm{b}, \mathrm{d}}$ \\
\hline a,b,c,d Different superscript letters within columns are significant $(p<0.05)$. The significant relationship between the two components is denoted by the \\
common superscript symbol.
\end{tabular}

value of crude fat compared with other Chyawanprash preparations. In contrast, the average concentration of crude fiber was found to be the least in brand C $(0.09 \pm 0.002 \mathrm{~g} / 100 \mathrm{~g})$ in comparison with all brands. The average concentration of protein was found to be the least in brand C $(0.60 \pm 0.25 \mathrm{~g} /$ $100 \mathrm{~g})$ in comparison with all brands. Likewise, brand $D$ was found to have the highest protein content $(5.36 \pm 0.83 \mathrm{~g} / 100 \mathrm{~g})$. It is then followed by brand A $(4.42 \pm 0.38 \mathrm{~g} / 100 \mathrm{~g})$, brand B $(2.63 \pm 0.28 \mathrm{~g} / 100 \mathrm{~g})$, and brand E $(2.02 \pm 0.29 \mathrm{~g} / 100 \mathrm{~g})$. High levels of carbohydrates were obtained in brand $\mathrm{C}$ $(88.13 \pm 1.78 \mathrm{~g} / 100 \mathrm{~g})$. Likewise, high levels of total energy were obtained in brand C $(363 \pm 11.90 \mathrm{Kcal} / 100 \mathrm{~g})$ followed by brand $\mathrm{D}(355 \pm 5.07 \mathrm{Kcal} / 100 \mathrm{~g})$ and least in brand $\mathrm{A}$ $(316.12 \pm 1.96 \mathrm{Kcal} / 100 \mathrm{~g})$ among all brands.

3.2. Physicochemical Analyses. The physicochemical analyses such as determination of $\mathrm{pH}$, acid-insoluble ash, alcohol-soluble extractive, and water-soluble extractive results of five different brands of Chyawanprash are shown in Table 2. The $\mathrm{pH}$ of different brands was approximately close to each other. The $\mathrm{pH}$ was in the range of 5.12-5.34, which is beyond the pharmacopoeial limit. Brand $\mathrm{E}$ was found to be on the basic side, whereas brand A Chyawanprash was acidic. Brand E contained a high amount of acid-insoluble ash (i.e., 1.47\%), which was beyond the limit of API 2001. Acid-insoluble ash as per the API 2007 should not be more than $1 \%$. In our study, brand D was found to have the lowest value for acid-insoluble ash in comparison with other brands of Chyawanprash preparations. All the brands contained alcohol-soluble extractives in the normal range. Among them, brand $\mathrm{D}$ contained the highest amount of acid-insoluble ash followed by brands A, C, E, and B. Likewise, all the brands contained water-soluble extractives in the normal range.

3.3. Estimation of Vitamin C. The analysis of vitamin $C$ in the samples showed a remarkable concentration, which is shown in Table 3. The results showed that the average vitamin C content was lowest in brand $\mathrm{E}, 9.92 \pm 0.69 \mathrm{mg} / 100 \mathrm{~g}$, and highest in brand A, $28.58 \pm 0.82 \mathrm{mg} / 100 \mathrm{~g}$.

3.4. Determination of Microbial Contamination and Identification of Microbes. The determination of total viable aerobic count in Chyawanprash is shown in Table 4. Of the five brands processed in the microbiology laboratory, all of the brands except brand A showed microbial growth, which was monomicrobial.

Further, Table 5 shows the details about the isolation of microorganisms. Isolation and identification confirmed that brands $\mathrm{B}, \mathrm{C}, \mathrm{D}$, and $\mathrm{E}$ were contaminated with Bacillus species.

3.5. Estimation of Heavy Metal, Lead, and Cadmium. Lead and cadmium were not in detectable range in parts per million (ppm) in any selected brands.

\section{Discussion}

In developing countries such as Nepal, no strict regulatory authority regulates the manufacture of herbal preparations or certifies the labeling of herbal preparations. Chyawanprash is used as a health tonic by men, women, children, and senior citizens in our country and has a vast market. It is a well-known ayurvedic formulation manufactured by many manufacturers nowadays. Still, the original method of Chyawanprash is lost in between its preparation and promotion in the market. The company manufacturing the product in large quantities requires the bulk amount of the rare herbs, so there may be the chance of adulteration. Therefore, a lack of standardization and quality assessment leads to a decrease in a quality of products, and this is the area that needs to be addressed. Hence, the quality assessment is necessary. The data obtained from the analysis of this study could be used for the quality control systems to ensure the safety of herbal medicines. Various scientific investigations regarding the adulteration of herbal drugs with harmful metals, steroids, NSAIDs, and other synthetic drugs leading to toxic effects on health have been reported [15]. Hence, quality assessment is an urgent necessity from the safety point of view and its acceptability in the modern system. We have confined only up to this analysis due to the lack of standardized instruments, income sources, and the availability of the laboratory in our context.

In the current study, the proximate analyses showed the moisture content ranging from $11.83 \pm 1.61 \%$ to $19.90 \pm 0.92 \%$. The limit for the moisture content of Chyawanprash given by the Ayurvedic Pharmacopoeia of India (API) 2007 [12] is not more than 9\%. Here, all selected brands were out of the limit and did not comply with the specification. A study conducted by Wagh et al. found the moisture content ranging from 2.9 to $5.1 \%$, which was less 
TABle 2: Physicochemical evaluation of Chyawanprash (average \pm standard deviation).

\begin{tabular}{lccccc}
\hline Components & Brand A & Brand B & Brand C & Brand D & Brand E \\
\hline $\mathrm{pH}$ & 5.15 & 5.12 & 5.29 & 5.19 & $0.12 \pm 0.05$ \\
Acid-insoluble ash & $0.15 \pm 0.02$ & $0.260 \pm 0.08$ & $0.23 \pm 0.02$ & $1.47 \pm 0.26$ \\
Alcohol-soluble extractive & $17.91 \pm 0.96$ & $15.51 \pm 2.19$ & $17.15 \pm 1.21$ & $18.99 \pm 1.02$ & $16.89 \pm 1.72$ \\
Water-soluble extractive & $19 \pm 0.76$ & $21.33 \pm 0.99$ & $18.11 \pm 0.59$ & $20.24 \pm 1.61$ & $20.03 \pm 1.09$ \\
\hline
\end{tabular}

Note. Only insignificant relationship exists between different components $(p>0.05)$.

TABLE 3: Vitamin C content in $\mathrm{mg} / 100 \mathrm{~g}$ (average \pm standard deviation).

\begin{tabular}{lr}
\hline Brand & Vitamin C \\
\hline A & $28.58 \pm 0.82$ \\
B & $27.76 \pm 0.68$ \\
C & $23.86 \pm 0.68$ \\
D & $24.44 \pm 0.69$ \\
E & $9.92 \pm 0.68$ \\
\hline
\end{tabular}

TABLE 4: Determination of total viable aerobic count in Chyawanprash.

\begin{tabular}{|c|c|c|c|c|c|}
\hline $\begin{array}{l}\text { S. } \\
\text { no. }\end{array}$ & Brands & $\begin{array}{l}\text { Volume examined } \\
\qquad(\mathrm{ml})\end{array}$ & $\mathrm{CFU} / \mathrm{ml}$ & $\begin{array}{c}\text { Microbial contamination limit for herbal } \\
\text { formulations as } \\
\text { per WHO guidelines }\end{array}$ & $\begin{array}{l}\text { Observation as per WHO } \\
\text { guidelines }\end{array}$ \\
\hline 1 & A & 10 & - & & No bacterial growth \\
\hline 2 & B & 10 & 27 & & $\begin{array}{l}\text { Lower than microbial contamination } \\
\text { limit }\end{array}$ \\
\hline 3 & $\mathrm{C}$ & 10 & 48 & $10 \wedge 5$. & $\begin{array}{l}\text { Lower than microbial contamination } \\
\text { limit }\end{array}$ \\
\hline 4 & $\mathrm{D}$ & 10 & 279 & & $\begin{array}{l}\text { Lower than microbial contamination } \\
\text { limit }\end{array}$ \\
\hline 5 & $\mathrm{E}$ & 10 & 51 & & $\begin{array}{l}\text { Lower than microbial contamination } \\
\text { limit }\end{array}$ \\
\hline
\end{tabular}

Note. Safety limits $\left(\mathrm{CFU} / \mathrm{g} \leq 10^{5}\right)$ according to WHO guideline for aerobic bacteria.

TABLE 5: Isolation of microorganisms.

\begin{tabular}{lcc}
\hline S. no. & Brands & Bacterial species \\
\hline 1 & A & - \\
2 & B & Bacillus spp. \\
3 & C & Bacillus spp. \\
4 & D & Bacillus spp. \\
5 & E & Bacillus spp. \\
\hline
\end{tabular}

than our study and well within the limit as per the Ayurvedic Pharmacopoeia of India (API) [16]. A similar study by Kumar et al. also found the moisture content of 5 different brands of Chyawanprash was within the limit as per the specification [17]. Since the moisture content is the leading factor responsible for the deterioration of the products, the excessive moisture content leads to the growth of microbes, fungi, and hydrolysis of the product and the low moisture content is always desirable for the higher stability of the product [18]. But the higher amount of moisture content in the entire brands suggested that it might be the reason for the microbial contamination of the products [19]. However, the low moisture content in brand A compared with the other brands could be the reason for the product being less susceptible to microbial contamination among the entire brands.
The present study revealed that the ash content was within the range. Brand $\mathrm{E}$ with the highest ash content and the least ash content was found in brand B as compared to other brands. The limit given by the API 2007 [17] for the total ash content is not more than $2 \%$. All brands passed the pharmacopoeial limit except brand E, which did not comply with the specification. A similar study conducted by Wagh et al. [16] found the ash content of 5 different samples of Chyawanprash was in the range of $1.2-2.3 \%$, whereas the study conducted by Sharma et al. shows that the ash content of 8 different samples was in the range of $1.44-2 \%$ [1], which seems to be similar to our study. Another study by Kumar et al. [17] in 5 different brands of Chyawanprash revealed that the data obtained were within the pharmacopoeial limit. In contrast, our study showed that only one of the brands was out of the limit. Ash represents inorganic salt naturally occurring in the preparation, or it may be intentional adulteration and substitution or carelessness in preparing formulation. It represents the purity or quality of plant material $[17,20]$. The results obtained in the study were within the specified limit except for brand $\mathrm{E}$, with the maximum value indicating the presence of maximum inorganic material in it. The minimum value was obtained with brand $B$, which suggested its good quality. 
The presence of indigestible carbohydrates and lignin is the indication of crude fiber. Crude fiber is made up mainly of cellulose with a little lignin and is indigestible in humans. Crude fiber enhances digestibility, but the higher level of fiber content may lead to intestinal irritation, lower digestibility, and decreased nutrient usage. Thus, a low amount of fiber content is appropriate [21, 22]. From the results obtained, crude fiber was recorded to be highest in brand $\mathrm{A}$ and lowest in brand $\mathrm{C}$ as compared to the other brands. A similar study by Ghosh A et al. conducted comparative standardization of new and old samples of Chyawanprash and found the fiber content to be $9.66 \pm 0.08 \%$ and $8.52 \pm 0.1 \%$ in new and old samples, respectively, which was much higher than our study [23].

A study by Soni HK et al. found the protein content of the herbal capsule containing Ashwagandha as a single herb to be $8.29 \%$ and suggested the product to be a dietary supplement [24]. Though the historical composition of Chyawanprash does not include Ashwagandha, some companies add it in place of the Ashtakavarga alternative. In our study, the protein content in brand $D$ was found to be maximum than other and was found to be following the study of Soni HK et al. Though it contains a low amount of protein content, to some extent it has some nutritive value and can contribute to the daily protein requirement body. Soni et al. [24] also found the carbohydrate content of the Ashwagandha, capsule to be $84.56 \%$, which seems to be similar to our study. Another study found $60.08 \%$ of the carbohydrate content in nutritional biscuits, which were lower than our study [21]. The literature supported that Chyawanprash can also be a dietary supplement with good nutritional value [21].

The energy value was found in the range of $316.12 \pm 1.96-363 \pm 11.90 \mathrm{Kcal} / 100 \mathrm{~g}$. Looking at the energy value, brand $\mathrm{C}$ has the highest energy value and brand $\mathrm{A}$ has the lowest energy value among the entire selected brands. An average person requires 2000-3000 energy Kcal/day, and the obtained data suggested that it can contribute to the caloric requirement of the body [25].

The physicochemical analyses showed the $\mathrm{pH}$ in the range of 5.12-5.34. A similar study by Wagh et al. found a $\mathrm{pH}$ of $1 \%$ aqueous solution within the range of 3.77-4.85, which was more acidic than our study [8]. The limit given by the pharmacopoeia for $\mathrm{pH}$ ( $1 \%$ aqueous solution) is in the range of 3.82-4.23. Though the $\mathrm{pH}$ of all of the selected brands was close to each other, they did not comply with the specification, and all were out of the limit.

An indication of silicate impurities that might have arisen due to improper washing of crude drugs is an acidinsoluble ash content [17]. The limit mentioned in pharmacopoeia is not more than $1 \%$ [12]. Looking at the results, all of the brands passed the limit except brand E, which was out of the given limit. As per the results, brand $\mathrm{E}$ with the maximum value could be related to the highest ash content in the same brand and indicate the presence of maximum earthy matter in it [17].

Acid-insoluble ash content was in the range of $0.12 \pm 0.05-1.47 \pm 0.26 \%$. It showed that brand $\mathrm{E}$ has the highest values for acid-insoluble ash content and brand D with the least values compared with that of other brands. The limit given by the API [12] for alcohol-soluble extractive and water-soluble extractive is not less than $50 \%$. The obtained results showed that all brands did not pass the limit as per the specification. The value of alcohol-soluble extractives and water-soluble extractive was less in the study of Wagh et al. [16].

The extractive value indicates the active constituents extracted with solvents from a given amount of material [17]. The major water-soluble polar constituents of crude drugs are tannins, sugar, plant acids, mucilage, glycosides, etc., and such are determined by water extractive value [17]. The lower values of extractive values in the case of brand $C$ suggested fewer amounts of active constituents (tannins, sugar, plant acids, mucilage, and glycosides) than other brands.

Vitamin C supports the antioxidant property of Chyawanprash [17]. Even though the official methods for quality evaluation of Chyawanprash do not include vitamin C content [12], but as per the results obtained, vitamin $C$ was present in all of the brands, although its content differed among them. The major vitamin $\mathrm{C}$ contributing medicinal plant in Chyawanprash is Emblica officinalis, i.e., Amala [17]. In our study, from the available labeled brand, the amount of Emblica officinalis in the different brands was in the range of $2.88-90 \mathrm{~g}$ in each $100 \mathrm{~g}$ per the label found in the sample. And from the study, the vitamin $\mathrm{C}$ content in different brands was found to be in the range of $9.92-28.58 \mathrm{mg} / 100 \mathrm{~g}$. According to the results, brand $\mathrm{A}$ has the highest concentration of vitamin $\mathrm{C}$ among all, and brand $\mathrm{E}$, with the least concentration. The results showed that all of the brands have the approximately same concentration as they are close to each other except brand $\mathrm{E}$, which has far less concentration than others.

Heavy metal is a metallic chemical element with high density and is relatively toxic and poisonous at any concentration. It causes irritation to the lungs, eyes, and skin, damages the nervous systems, and causes cancer of the skin, lung, liver, and nose. Heavy metal poisoning can cause dermatitis and harm the brain and nerve functions, anemia, and kidney damage $[26,27]$. The present study revealed no detectable amount of lead and cadmium in any of the brands in ppm. The permissible limit given by the Ayurvedic Pharmacopoeia of India [12] for lead is $10 \mathrm{ppm}$ and cadmium is $0.30 \mathrm{ppm}$. Our study was found to be under the study conducted in Nepal by Ojha A et al., and none of the selected ayurvedic remedies contained a detectable amount of lead in parts per billion [28]. Another study on ayurvedic churna preparation [9] found that the lead and cadmium were all above the permissible limit. In contrast, our study did not find the detectable amount of lead and cadmium.

Microbial quality of the tested brands suggested that brand $\mathrm{A}$ was free from the microbial contamination and all the other brands were contaminated by the Bacillus spp., which was comparable to the study conducted by Shah B and Pokhrel N, where Bacillus spp. were isolated from ten herbal medicines. Altogether, 6 different Bacillus species were determined where Bacillus subtilis was predominant [29]. 
The presence of bacteria could be explained by the fact that these bacteria produce spores and they are resistant to the harsh environment, elevated heat, and dry conditions and they can survive for a long time in a product remaining in a dormant state [30]. The bacteria pollution may have been originated from the handling of raw materials during the manufacturing process [31]. Microbial contamination in the product could also be due to the inappropriate harvesting, cleaning of raw materials, unsuitable transport, and storage of the raw materials [32]. Further experiments on different spectroscopic techniques should be used to validate the experimental grounds.

\section{Conclusion}

This preliminary study has demonstrated that Chyawanprash in Nepal is of good quality based on proximate analyses and physicochemical composition agreeing with the literature review. This study recommends that due to the adequate amount of carbohydrate, total energy, protein, and fiber content in Chyawanprash, it can be used as a nutritional health supplement. However, for the uniformity of the different brands and to reduce the variations of the product, strict quality parameters should be implemented from the government level. And manufacturers should be encouraged to send their products to laboratories for quality assessment to ensure the consistency and quality of the products before being marketed. Therefore, for further validation, more research should be carried out on Nepali marketed Chyawanprash.

\section{Abbreviations}

GMP: $\quad$ Good manufacturing practices

API: $\quad$ Ayurvedic Pharmacopoeia of India

AOAC: Association of Official Agricultural Chemists

WHO: World Health Organization

NSAIDs: Nonsteroidal anti-inflammatory drugs.

\section{Data Availability}

The data used to support the findings of this study are available from the corresponding author upon request.

\section{Ethical Approval}

Ethical approval was obtained from the Manmohan Memorial Institute of Health Sciences (MMIHS) and the Department of Food Technology and Quality Control.

\section{Conflicts of Interest}

The authors declare that they have no potential conflicts of interest.

\section{Authors' Contributions}

B.A designed research; K.G performed research; B.A., P.P., and K.G analyzed data; and B.A., P.P., K.G., S.S., and D.P.K wrote the article.

\section{Acknowledgments}

The authors are grateful to the Manmohan Memorial Institute of Health Sciences (MMIHS) Research Laboratory, Department of Food Technology and Quality Control, Ministry of Agriculture and Cooperatives, Babarmahal, Kathmandu, and Nepal Bureau of Standards and Metrology, Machhapokhari, Kathmandu, to perform these experiments.

\section{References}

[1] M. Sharma, C. Martins, R. Kuca et al., "Chyawanprash: a traditional Indian bioactive health supplement," Biomolecules, vol. 9, no. 5, p. 161, 2019.

[2] C. J. Shishoo, S. A. Shah, I. S. Rathod, and S. G. Patel, "Determination of vitamin C content of Phyllanthus emblica and chyavanprash," Indian Journal of Pharmaceutical Sciences, vol. 59, p. 268, 1997.

[3] P. Debnath, J. Chattopadhyay, A. Mitra et al., "Adjunct therapy of Ayurvedic medicine with anti tubercular drugs on the therapeutic management of pulmonary tuberculosis," Journal of Ayurveda and Integrative Medicine, vol. 3, no. 3, p. 141, 2012.

[4] D. B. A. Narayana, S. Durg, P. R. Manohar, A. Mahapatra, and A. R. Aramya, "Chyawanprash: a review of therapeutic benefits as in authoritative texts and documented clinical literature," Journal of Ethnopharmacology, vol. 197, pp. 52-60, 2017.

[5] A. Gupta, S. Kumar, S. Dole et al., "Evaluation of Cyavanaprāśa on health and immunity related parameters in healthy children: a two arm, randomized, open labeled, prospective, multicenter, clinical study," Ancient Science of Life, vol. 36, no. 3, p. 141, 2017.

[6] M. Bode, "Assemblingcyavanaprāsh, Ayurveda's best-selling medicine," Anthropology and Medicine, vol. 22, no. 1, pp. 23-33, 2015.

[7] L. Das, E. Bhaumik, U. Raychaudhuri, and R. Chakraborty, "Role of nutraceuticals in human health," Journal of Food Science \& Technology, vol. 49, no. 2, pp. 173-183, 2012.

[8] G. S. Matos, S. G. Pereira, Z. A. Genisheva, A. M. Gomes, J. A. Teixeira, and C. M. R. Rocha, "Advances in extraction methods to recover added-value compounds from seaweeds: sustainability and functionality," Foods, vol. 10, no. 3, p. 516, 2021.

[9] M. Garg and J. Singh, "Quantitative AAS stimation of heavy metals and trace elements in marketed ayurvedic churna preparations in India," International Journal of Pharmaceutical Sciences and Research, vol. 3, p. 1331, 2012.

[10] A. Balekundri and V. Mannur, "Quality control of the traditional herbs and herbal products: a review," Future Journal of Pharmaceutical Sciences, vol. 6, no. 1, p. 67, 2020.

[11] A. O. AC. Offical, Methods of Analysis, Association of Official Analytical Chemists, Arlington VA, USA, 15th edition, 1990.

[12] The Ayurvedic Pharmacopoeia of India, "Part-II (formulations)," vol. II, 1st edition, 2007.

[13] S. S. Nielsen, "Vitamin C determination by Indophenol method," in Food Analysis Laboratory Manual, S. S. Nielsen, Ed., Springer International Publishing, Cham, Switzerland, pp. 143-146, 2017.

[14] K. Belay, A. Tadesse, and T. Kebede, "Validation of a method for determining heavy metals in some ethiopian spices by dry ashing using atomic absorption spectroscopy,” p. 1, 2015.

[15] C. Kahraman, Z. Ceren Arituluk, and I. Irem Tatli Cankaya, "The clinical importance of herb-drug interactions and 
toxicological risks of plants and herbal products," Medical Toxicology, 2020.

[16] V. D. Wagh, S. V. Patil, and M. G. Kalaskar, "Comparative standardization of a polyherbal formulation chyavanaprasam," Malaya Journal of Biosciences, vol. 1, pp. 173-180, 2014.

[17] A. Kumar, P. Kaur, and P. Rinwa, "Evaluation of morphological, phytochemical and physicochemical properties of Indian polyherbal formulation," Chyawanprash for Quality Evaluation, vol. 1, p. 21, 2012.

[18] K. D. Hyde, J. Xu, S. Rapior et al., "The amazing potential of fungi: 50 ways we can exploit fungi industrially," Fungal Diversity, vol. 97, no. 1, pp. 1-136, 2019.

[19] O. Kambire, K. M. Yao, A. E. Sika, A. Coulibaly, Z. B. I. A. Boli, and R. Koffi-Nevry, "Microbiological and physicochemical characteristics of three types of "soumbara" from seeds of african locust bean in korhogo markets, côte d'Ivoire," International Journal of Food Science, vol. 2021, Article ID 5572300, 6 pages, 2021.

[20] A. N. M. Alamgir, "Herbal drugs: their collection, preservation, and preparation; evaluation, quality control, and standardization of herbal drugs," in Therapeutic Use of Medicinal Plants and Their Extracts: Volume 1: Progress In Drug Research, A. N. M. Alamgir, Ed., Springer International Publishing, Cham, Switzerland, pp. 453-495, 2017.

[21] M. Mehta, "Development of low cost nutritive biscuits with Ayurvedic formulation," International Journal of Ayurvedic and Herbal Medicine, vol. 3, pp. 1183-1190, 2013.

[22] G. C. Fahey, L. Novotny, B. Layton, and D. R. Mertens, "Critical factors in determining fiber content of feeds and foods and their ingredients," Journal of AOAC International, vol. 102, no. 1, pp. 52-62, 2019.

[23] A. Ghosh, DrD. Laloo, and DrN. Singh, "Comparative estimation and chemical standardization of new and old sample of Chyawanprash," International Journal of Pharmacy and Pharmaceutical Sciences, vol. 5, pp. 801-804, 2013.

[24] H. K. Soni, N. C. Ribadiya, S. B. Bhatt, and N. R. Sheth, "Evaluation of herbal formulation (capsule) containing Ashwagandha as a single herb with their nutritional value determination," International Journal of Applied Biology and Pharmaceutical Technology, vol. 1, no. 3, pp. 960-967, 2010.

[25] U. D. Akpabio and E. E. Ikpe, "Proximate composition and nutrient analysis of Aneilema aequinoctiale leaves," Asian Journal of Plant Science \& Research, vol. 3, pp. 55-61, 2013.

[26] P. N. Obasi and B. B. Akudinobi, "Potential health risk and levels of heavy metals in water resources of lead-zinc mining communities of Abakaliki, southeast Nigeria," Applied Water Science, vol. 10, no. 7, p. 184, 2020.

[27] G. Azeh Engwa, P. Udoka Ferdinand, F. Nweke Nwalo, and M. Unachukwu, "Mechanism and health effects of heavy metal toxicity in humans," in Poisoning in the Modern World New Tricks for an Old Dog? IntechOpen, O. Karcioglu and B. Arslan, Eds., 2019.

[28] A. Ojha, "In vitro estimation of lead content in Nepalese traditional ayurvedic medicines commonly used in children," Journal of Nepal Paediatric Society, vol. 33, no. 2, pp. 103-105, 2013.

[29] B. Shah and N. Pokhrel, "Microbial quality and antibacterial activity of herbal medicines," Nepal Journal of Science and Technology, vol. 13, pp. 191-196, 2012.

[30] T. Stevic, S. Pavlovic, S. Stankovic, and K. Savikin, "Pathogenic microorganisms of medicinal herbal drugs," Archives of Biological Sciences, vol. 64, no. 1, pp. 49-58, 2012.
[31] A. Uçar, M. V. Yilmaz, and F. P. Çakiroglu, "Food safety problems and solutions," in Significance, Prevention and Control of Food Related Diseases, H. A. Makun, Ed., 2016.

[32] A. Valero, M.-Y. Rodríguez, G. D. Posada-Izquierdo, F. PérezRodríguez, E. Carrasco, and R. M. García-Gimeno, "Risk factors influencing microbial contamination in food service centers," in Significance, Prevention and Control of Food Related Diseases, H. A. Makun, Ed., 2016. 